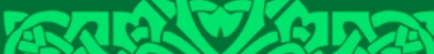
520030102 का 10 4 t


o 21205 रत्र 202 cos (2) 120

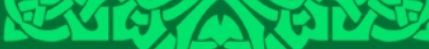
पis 4 कि

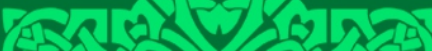
पित 1 (1) 0 (0)

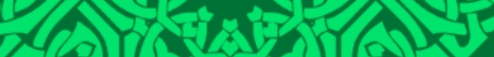
of 2505105 रन्तिए 0 cos 12 an


परत w कि Tat


520100103 20 (1) 5 (5)
Sandra Dewi Dahlan, Mirotin Eka Wahyuningsih, Hasbi Assiddiqi, Edi Ardian, Rahmat Fajar The Role of Gossip as a Strategy to Reach Power in Tilik Short Movie

Hasaruddin, Sitti Mania, Ahmad Yani, Musyarif Tracking The Historical Development of Kedatuan Sawitto in South Sulawesi in The XVI-XVII Century

Abdul Muiz Amir, Sahiron Syamsuddin, Siswanto Masruri Dialectic Relationship Between The Qur'an and Hadith: The Interpretation of The Term "As-Sä'Ah" Using Critical Hermeneutic Analysis

Fachmi Alhadar, Safrudin Amin Covid-19 Poems as Cultural Response to Pandemic in Indonesia

Arini Indah Nihayaty, Bagong Suyanto, Sutinah A Study of Religious Symbols Attached to The Former Terrorist Convicts' Family as Seen in Social Interaction Wahyuddin, M. Abdul Hamid محاولات شوقي ضيف التجيديدية في تيسير النحو التعليمي

M. Napis Djuaeni, Hasyim Ashari نظام القافية ودوره في نشأَة المعاجم اللغوية العربية

Hasyim Haddade, Baso Pallawagau, Zaenal Abidin, Muhammad Zakir Husain التجديد في النحو: در اسة مذهب الخطيب الثربيني اللغوي في تفسيره السراج المنير

Nurhakki, Ahmad Sultra Rustan, Muhammad Taufiq Syam The Habituation of Tongkonan Communication as Adhesives for Religious Harmony in Toraja People

Nahdhiyah, Syahruni Junaid A Study of Al Qur'an towards Environmental Issues of Buginese ElongElong (Ecocritical Approach) UNIVERSITAS ISLAM NEGERI ALAUDDIN 


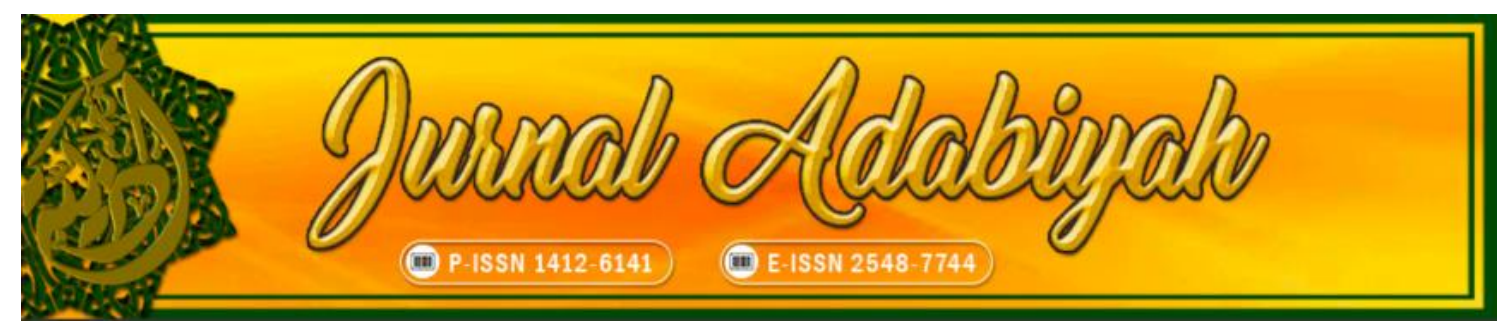

Theme: Humanities

VOLUME 21 NO. 1 JUNE 2021

\section{EDITOR-IN-CHIEF}

Nuri Emmiyati, Alauddin State Islamic University, Indonesia

\section{ASSOCIATE EDITOR}

Barsihannor, Alauddin State Islamic University, Indonesia

\section{INTERNATIONAL EDITORIAL BOARD}

Shamsi Ali, University of Northern California, United States

Miss Tiarne Jade Barratt, University of Sydney, Australia

Muhammad Widus Sempo, Universiti Sains Islam Malaysia, Malaysia

Salih Yousif Sharaf Mohamed, Al-Gazera University, Sudan

Aishah Waenaha Waemamah, Academy of Islamic and Arabic Studies Princess of Naradhiwas University

- Thailand, Thailand

\section{EXECUTIVE EDITOR}

Umar Thamrin, Alauddin State Islamic University, Indonesia

\section{MANAGING EDITOR}

Nasrum, Alauddin State Islamic University, Indonesia

\section{EDITORS}

Akbar Haseng, Institut Agama Islam Negeri Kendari, Indonesia Sardian Maharani Asnur, Alauddin State Islamic University, Indonesia Subehan Khalik Umar, Alauddin State Islamic University, Indonesia

Haniah, Alauddin State Islamic University, Indonesia

Andi Satrianingsih, Universitas Muhammadiyah Makassar, Indonesia

Awaluddin Syamsu, Universitas Muslim Indonesia

Muhammad Azwar, UIN Syarif Hidayatullah Jakarta, Indonesia

\section{ASSISTANT TO THE EDITORS}

Chusnul Chatimah Asmad, Alauddin State Islamic University, Indonesia

ENGLISH LANGUAGE ADVISOR

Rosmah Tami, Alauddin State Islamic University, Indonesia

Syahruni Junaid, Alauddin State Islamic University, Indonesia

\section{ARABIC LANGUAGE ADVISOR}

Muh. Saleh Syamsuri, Alauddin State Islamic University, Indonesia

Baso Pallawagau, Alauddin State Islamic University, Indonesia

\section{IT SUPPORT}

Taufiq Mathar, Alauddin State Islamic University, Indonesia

\section{COVER DESIGNER}

Nur Arifin 


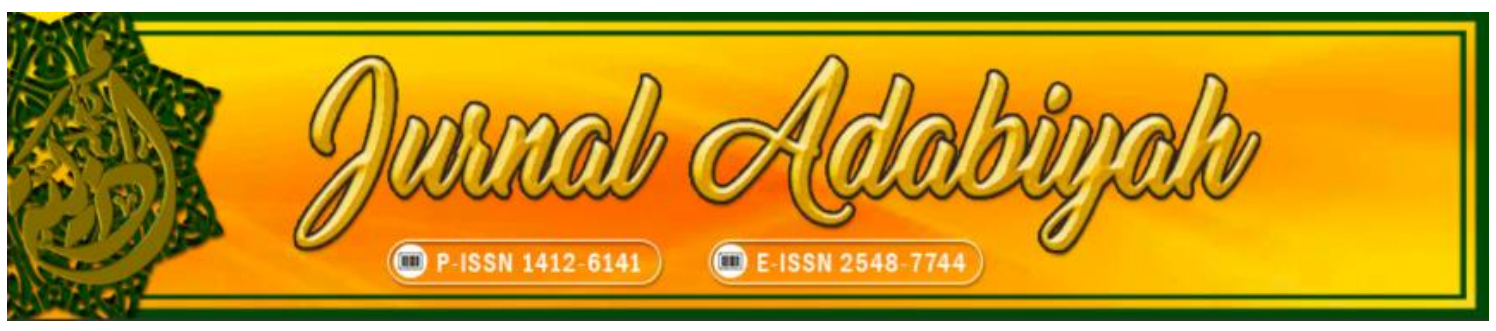

\section{Jurnal Adabiyah:}

This journal receives a national accreditation from Ministry of Research, Technology, and Higher Education Republic of Indonesia, Nomor 10/E/KPT/2019 on April 4, 2019 with the SINTA score: S2.

The Journal has been published by the Faculty of Adab and Humanity of Alauddin State Islamic University, Makassar, since 1997 and has been online since 2016 with the main themes on Humanities and Islamic Studies with the emphasis on interdisciplinary and intertextuality approach.

This journal are published twice a year, on June and December. The themes related to Islamic Studies are textual studies, scriptural traditions, Islamic law, and theology; and those related to Humanities are language, literature, history, and culture.

The journal of Humanities and Islamic Studies will provide the online collection of articles from 1997 up to now. The most updated information can be found on the website. 


\section{Table of Contents}

Besse Wahida, Khaerun Nisa Nuur, Ibnu Hajar Ansori

Tracing Entities of Arabic in The Qur'an

Sandra Dewi Dahlan, Mirotin Eka Wahyuningsih, Hasbi Assiddiqi,

Edi Ardian, Rahmat Fajar

The Role of Gossip as a Strategy to Reach Power in Tilik Short Movie

Hasaruddin, Sitti Mania, Ahmad Yani, Musyarif.

Tracking The Historical Development of Kedatuan Sawitto in South Sulawesi in The XVI-XVII Century

Abdul Muiz Amir, Sahiron Syamsuddin, Siswanto Masruri 57-81

Dialectic Relationship Between The Qur'an and Hadith: The Interpretation of The Term "As-Sā 'Ah" Using Critical Hermeneutic Analysis

Fachmi Alhadar, Safrudin Amin.

Covid-19 Poems as Cultural Response to Pandemic in Indonesia

Arini Indah Nihayaty, Bagong Suyanto, Sutinah

A Study of Religious Symbols Attached to The Former Terrorist Convicts' Family as Seen in Social Interaction

Wahyuddin, M. Abdul Hamid

محاولات شوقي ضيف التجبيليدية في تيسيل النحو الثعليهي

161-187

M. Napis Dj, Hasyim Ashari

نظام القافية ودوره في نشأة المعاجم اللغويا العربية

Hasyim Haddade, Baso Pallawagau, Zaenal Abidin,

Muhammad Zakir Husain

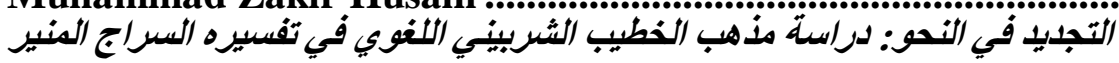

Nurhakki, Ahmad Sultra Rustan, Muhammad Taufiq Syam

The Habituation of Tongkonan Communication as Adhesives for Religious Harmony in Toraja People

Nahdhiyah, Syahruni Junaid

A Study of Al Qur'an towards Environmental Issues of Buginese ElongElong (Ecocritical Approach)

Jurnal Adabiyah Vol 21. Number 1/2021 


\title{
THE ROLE OF GOSSIP AS A STRATEGY TO REACH POWER IN TILIK SHORT MOVIE
}

\author{
Sandra Dewi Dahlan ${ }^{1}$, Mirotin Eka Wahyuningsih ${ }^{2}$, Hasbi Assiddiqi ${ }^{3}$, \\ Edi Ardian ${ }^{4}$, Rahmat Fajar ${ }^{5}$ \\ Universitas Islam Negeri Alauddin Makassar ${ }^{1}$ \\ Universitas Islam Negeri Sunan Ampel Surabaya ${ }^{2}$ \\ Universitas Islam Negeri Sunan Gunung Djati Bandung ${ }^{3}$ \\ Universitas Islam Indragiri ${ }^{4}$ \\ Universitas Islam Negeri Sulthan Thaha Saifuddin Jambi ${ }^{5}$ \\ Email: sandra.dewi@uin-alauddin.ac.id ${ }^{1}$, mirotin.eka.wahyu.ningsih.m.a@ dlb.uinsby.ac.id ${ }^{2}$, \\ hasbi.assiddiqi@uinsgd.ac.id ${ }^{3}$, ediardian897@gmail.com4, rahmatfajar86@gmail.com5
}

\begin{abstract}
The complexity and distinctiveness of gossip and gossiping have highlighted the recent viral short movie, Tilik (2018). It is important to note that gossip has also been identified as a support in social attachment in large crowds which is used to gain certain power. This research analyzes the role of gossip and gossiping in reaching the power within a community and the instruments to reach such power. Hence, this qualitative research employs cultural study approach to get an in-depth and complete analysis based on cultural perspective. Besides, Social Dominance Theory is also applied to explore the usage of gossip as weapon to reach the top of power. The study shows that gossip is surely a sharp weapon that may attack either the object of gossip or others harmed by the formulation of gossip. Also, gossip can be activated as a weapon to reach power in a certain group. Furthermore, gossip can be effective if the person who spreads it has power in the society.
\end{abstract}

Keywords: Gossip; Power; Javanese Society; Tilik.

الملخص

تم تسليط الضيوء على تعقيدات وخصائص النميمة والقيل والقال في أحدث

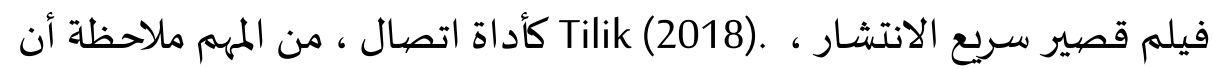

النميمة المحددة يمكن أن تساعد في تقوية الروابط الاجتماعية للعديد من

الناس وكذلك اكتساب القوة .تحلل هذه الدراسة دور النميمة والنميمة في

اكتساب التأثير )القوة (في المجتمع وكذلك الأدوات المستخدمة لتحقيق تلك

القوة .يسعى البحث النوعي بنهج ثقافي إلى الحصول على تحليل حاد ومتعمق

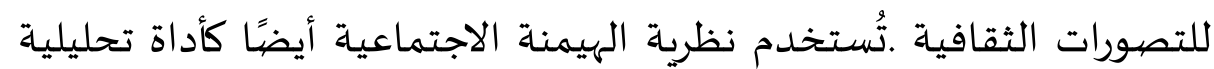




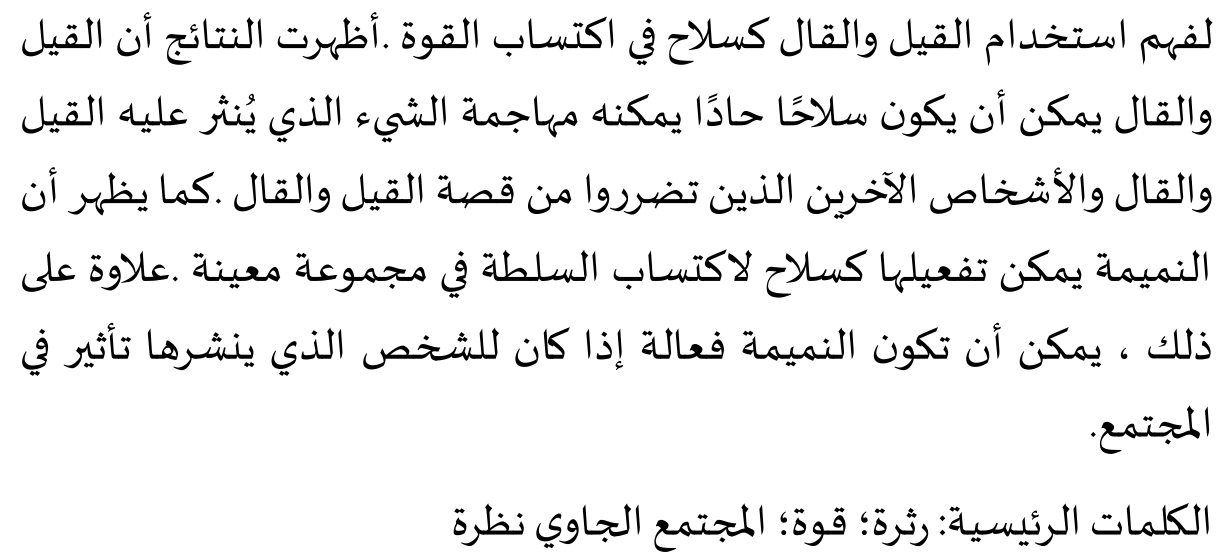

\begin{abstract}
Abstrak
Kompleksitas dan kekhasan gosip dan bergosip menjadi sorotan dalam film pendek viral terbaru, Tilik (2018). Sebagai alat komunikasi, penting untuk dicatat bahwa gosip teridentifikasi dapat membantu mempererat ikatan sosial banyak orang sekaligus meraih kekuasaan. Penelitian ini menganalisis peran gosip dan bergosip dalam mendapatkan pengaruh (kekuasaan) di dalam masyarakat serta instrument yang digunakan dalam meraih kekuasaan tersebut. Penelitian kualitatif dengan pendekatan budaya ini berupaya memperoleh analisis tajam dan mendalam dalam persepsi budaya. Teori dominasi sosial juga digunakan sebagai instrument analisis untuk memahami penggunaan gossip sebagai senjata dalam memperoleh kekuasaan. Hasil penelitian menunjukkan bahwa gosip dapat menjadi senjata tajam yang dapat menyerang objek tergosip maupun orang lain yang dirugikan oleh cerita gosip tersebut. Selain itu juga menunjukkan bahwa gosip dapat diaktifkan sebagai senjata untuk meraih kekuasaan pada suatu kelompok tertentu. Lebih jauh, gosip bisa efektif jika orang yang menyebarkannya memiliki pengaruh di masyarakat.
\end{abstract}

Kata Kunci: Gossip; Kekuasaan; Masyarakat Jawa; Tilik

\title{
A. Introduction
}

Gossip is related to the way a group of people has perspectives on a particular individual or other people on their behaviors, appearances, mistakes, habits, and other qualities. The perspectives are manifested in judgments and views based on clear or unclear evidences, solid or vague arguments, as well as fiction or non-fiction stories. Gossip is one of the communication forms within society. Joseph Epstein has observed the definition of the word "gossip", which includes the useful transmission of information along with the older implication of casual or unrestrained talk about other human beings. It is not astonishing why people are interested in other people's 
business since other human beings are the world's most attractive topic. ${ }^{1}$ Moreover, Beersma, Gerben and Kleef declare that one of the gossiping motives is social enjoyment. Gossiping is viewed as a distraction from daily routine activities that help those who are involved in having fun. Hence, gossip is often defined under a negative perspective. ${ }^{2}$ Gossip is often seen as self-serving deeds aimed at manipulating other people and persuading them in some spiteful method. ${ }^{3}$ However, gap is always present on human knowledge of other people which makes them always lack the whole story. ${ }^{4}$ It means that gossip is usually established based on limited knowledge of the object of gossip which provides no guarantee for its truth.

It is important to note that gossip has also been identified as assisting social attachment in large crowds. ${ }^{5}$ When people talk about something, the curiosity to know and investigate the object of gossip somehow shows our necessity in involving to fulfill our desire to bond with our social group. However, Daniel Solove warns that human judgment is imperfect; Human judgment is made of pieces of information taken out of context. ${ }^{6}$

The explanation above is in line with the characteristic of gossip presented by Clare Birchall. Clare Birchall states the characteristics of gossip: 1) gossip is informal talk, 2) conducted within a very small group of participants, 3) who know each other fairly well, and 4) trust one another not to violate each other's confidence. 5) The subject matter is highly personal, focused on knowledge of other people, and 6) the person or people who form the subject matter are not among those doing the discussing.

Gossip is not a new material employed in art-works. Mark Twain, the $19^{\text {th }}$ century American writer, employed gossip as one of his writing style. Such style can be found in The Celebrated Jumping Frog of Calaveras County, a short story. F. Scott Fitzgerald, another American writer and one of the members of lost generation writers, wrote The Great Gatsby based on the power of gossip and rumor. In more recent work, we found American TV series Gossip Girl, and Indonesia is without

2011)

${ }^{1}$ Joseph Epstein, Gossip: The Untrivial Pursuit, 1st ed. (Boston: Houghton Mifflin Harcourt,

${ }^{2}$ Bianca Beersma and Gerben A. Van Kleef, "Why People Gossip: An Empirical Analysis of Social Motives, Antecedents, and Consequences," Journal of Applied Social Psychology, 2012, https://doi.org/10.1111/j.1559-1816.2012.00956.x.

${ }^{3}$ Beersma and Van Kleef.

${ }^{4}$ Daniel Solove, "'I've Got Nothing to Hide' and Other Misunderstandings of Privacy," San Diego Law Review 44, no. 4 (2007): 745.

${ }^{5}$ R I M Dunbar, "The Vindication of Gossip," Review of General Psychology 8, no. 2 (June 2004): 100-110, https://doi.org/10.1037/1089-2680.8.2.100.

${ }^{6}$ Dunbar.

${ }^{7}$ CLARE Birchall, "Knowledge Goes Pop From Conspiracy Theory to Gossip," Journal of Chemical Information and Modeling 53, no. 9 (2019): 1689-99, https://doi.org/10.1017/CBO9781107415324.004. 
exception. Gossip also becomes a noticeable focus on the recently viral short movie in Indonesia, Tilik (2018). ${ }^{8}$

The complexity and distinctiveness of gossip and gossiping have highlighted the short movie Tilik (2018). Tilik is a 32 minutes short movie that tells about a group of housewives who are gossiping on the truck. The gossiping happens along their way to a hospital visiting $B u$ Lurah (Village Headwoman), which is why the short movie also named Tilik (visiting). Uploaded premiered on August 17, 2020, on YouTube, Tilik has gained huge popularity in Indonesia and has been watched by more than 24 million viewers just in two months. On Jakarta Post, Jessica Valentine notices that ghibah (gossiping) and emak-emak (housewives) have become viral catchphrases on social media in the latest days, because of the short movie Tilik. ${ }^{9}$

Becoming the recent viral phenomenon, Tilik is under spotlight for the debatable content, specifically on the women and the gossip among them. Such subject instills the debate among not only those who are professionally involved in the movie industry but also general public. Julia Suryakusuma in her article on Jakarta Post states the reality that Tilik is viral should encourage us to think about the Indonesian Constitution, collective sanity, Pancasila as well as the future of Islam. She believes that our collective consciousness on idealizing $\mathrm{Bu}$ Tedjo, the main character and center of gossip, is the way people encouraging the negative stereotype of women. ${ }^{10}$ This movie becomes viral because it shows the reality in our daily social life, where people like to gossip.

As a social bonding aid, gossip somehow can be used as the main topic in people's chat. In the short movie Tilik, gossip becomes an integral part of the plot that drives the story from the beginning until the end. As the plot goes by, viewers observe the characters' personality in the movies through their perception toward gossip. Niko Besnier believes there is an actor played his/her role to strive for a certain goal in the process of gossip. ${ }^{11}$ In Tilik, the actors who dominate the process of gossiping are $\mathrm{Bu}$ Tejo, Bu Tri, Yu sam, and $\mathrm{Yu}$ Ning. Viewers are presented by the unique characterizations of $\mathrm{Bu}$ Tejo and $\mathrm{Bu}$ Tri, the characters that support gossip and even provoke it. Another type of character is represented by Yu Ning who strongly disagrees with any unqualified news. There is also a type of character that involved in gossip but does not fully support the whole idea represented by Yu Sam. Other characters portrayed are other women in the truck who tend to passively receive the

\footnotetext{
${ }^{8}$ Wahyu Agung Prasetyo, Tilik, 2018.

9 Jessicha Valentina, "Short Film 'Tilik' Grabs Netizens; Attention with 'Ghibah', 'emakEmak",," The Jakarta Post, 2020. Post, 2020

${ }^{10}$ Julie Suryakusuma, “Tilik', Sexist Stereotypes and Our Collective Insanity," The Jakarta

${ }^{11}$ Niko Besnier, Gossip and the Everyday Production of Politics, Gossip and the Everyday Production of Politics, 2009, https://doi.org/10.1111/j.1757-6547.2011.00114.x.
} 
gossip. Also, Besnier believes that gossip also breaks and damages the harmony in the society. Thus, the dispute among women who are gossiping on the truck occurs. ${ }^{12}$

Tilik also presents the object of gossip, a young woman named Dian-her physical looks, her personality, and her scandal that are delivered in the truck. McAndrew states the main purpose of gossip is to reinforce the lack of morality and accountability. ${ }^{13}$ People's tendency to talk about someone's bad behavior behind their back is seen as a medium to punish and share the common idea among people. Dian as the object of gossip is selected as suggested by Epstein as long it is an interesting topic of talk whether the talk is merely opinion. Joseph Epstein states that talk is likely about the great subjects and occasion and problems, about which most of us activate in the territory of just opinion or everything that is exciting to say. ${ }^{14}$ It can be classified as passive aggression since the person we talk is not around but people still can show their power by harming that person. ${ }^{15}$

Based on the power hold by the gossiper, it can be concluded that gossip is related to the process of gaining power. Niko Besnier declares that gossiper(s) who hold and engage the information as precious commodity may accumulate it in the capitalistic fashion. ${ }^{16}$ It means the content of gossip become valuable commodity to gain advantage. In Tilik, the process of gaining the advantage is pursued by $\mathrm{Bu}$ tejo. $\mathrm{Bu}$ Tejo, the main character in the movie, consistently sparks and spreads gossip during the trip. We notice that since the beginning of the movie until the end of it, she is the one who creates conversation among the women on the truck. It is interesting to see how this character harnesses her power through gossip in driving people's thoughts. The character is very vocal in delivering gossip and her opinion especially about Dian while the other women on the truck tend to listen to her. Socially $\mathrm{Bu}$ Tedjo is portrayed as a very dominant character in her communal relationship. Observing this fact, this research is going to focus on the role of gossip and gossiping in gaining power within a community. Such power can be achieved by describing the social dominance in the communal relationship. Social Dominance discusses how people are structurally divided based on their social hierarchies as systems of groups.

There have been several numbers of research discussing Tilik. Inayaturrobbani, analyzes the dynamics of gossip activities in Tilik. She employs the theory of Self-Concept Enhancing Tactician (SCENT) model, which the results shows that gossip has two prominent functions: self-protection and self-promotion. Selfpromotion involves the emotion of pride and self-protection involves the emotion of

\footnotetext{
12 Besnier.

${ }^{13}$ Frank T. McAndrew, "The Science of Gossip: Why We Can't Stop Ourselves," Scientific American Mind, 2008.

${ }^{14}$ Epstein, Gossip: The Untrivial Pursuit.

${ }^{15}$ McAndrew, "The Science of Gossip: Why We Can't Stop Ourselves."

${ }^{16}$ Besnier, Gossip and the Everyday Production of Politics.
} 
fear. ${ }^{17}$ This research is different compared to the previous studies. This study discusses deeper impact of gossip. When Inayaturrobani believes that gossip in Tilik aims to gain self-protection and self-promotion, this research explores deeper than that. In fact, self-protection and self-protection is a ladder to gain more benefit called power. Power is the last goal of spreading gossip.

Another research is written by Christina that explores the language used by $\mathrm{Bu}$ Tejo, whose expressions are highly influencing in the movie, especially in her speech acts. She has found out that Bu Tejo's speech acts are mostly in the form of representation. ${ }^{18}$ This research is also different to Christina's research focus. This research explores that the expression, gesture, language, and appearance of $\mathrm{Bu}$ Tejo employs as weapon to convince others in the process of spreading gossip.

Based on the description above on the relation of gossip and power reflected by Tilik, this study will examine 1) the role of gossip as a strategy to gain power and 2) the significance elements portrayed by Tilik in delivering a convincing gossip and reaching the power (narration, social status, and strong appearance). It is interesting challenging to observe how the main character with her hegemony employs gossip as the strategy to reach power in Tilik short movie.

\section{B. Methodology}

In order to obtain a proper analysis, this employs qualitative method which is supported by cultural study approach. Qualitative research according to Ritchie and Lewis is directed at providing an in-depth and interpreted understanding of the social world of research participants by learning about their social and material circumstances, their experiences, perspectives, and histories. Moreover, they explained the main qualitative methods include: observation, in-depth individual interviews, focus groups, biographical methods such as life histories and narratives, and analysis of documents and texts. ${ }^{19}$

Cultural study approach is applied to Tilik remembering that this is the product of popular culture written based on local values. Analyzing the movie in the perspective of culture will enable the research to see complete picture of the movie based on cultural background and custom reference shown.

Furthermore, to understand the process of spreading gossip and gaining power Social Dominance theory will be applied as analysis instrument. In that sense, the Social Dominance Theory (SDT) is used to describe how gossip becomes the strategy

17 Fakhirah Inayaturrobbani, "Memahami Fungsi Gosip Dalam Masyarakat Melalui Film Pendek 'Tilik,"' TONIL: Jurnal Kajian Sastra, Teater Dan Sinema 17, no. 2 (2020): 41-54, https://doi.org/10.24821/tnl.v17i2.4353.

18 Chistina Christina, "The Analysis of Bu Tejo's Language in Short Movie 'Tilik," Metaphor 3, no. No 1 (2020).

19 G Ritchie, J., Lewis, J., \& Elam, "Designing and Selecting Samples.," in Qualitative Research Practice, 2003. 
to reach power in Tilik short movie. According to Tilly, Social Dominance Theory is an attempt to connect the worlds of individual personality and attitudes with the domains of institutional behavior and social structure. SDT starts with the fundamental review that in the society people tend to be structured based on social hierarchies as systems of group. ${ }^{20}$ This hierarchical social structure contains two different groups, at the top there is a small number of dominant and hegemonic groups and at the bottom is one or several subordinate groups. After such observation, SDT then attempts to identify the various mechanisms that produce and maintain this group-based social hierarchy and how these mechanisms interact. ${ }^{21}$ Therefore, the group-based social hierarchy, hegemonic group and its mechanism interaction will be analyzed in Tilik Movie. It is explained that in an individual-based social hierarchy, individuals might enjoy great power, prestige, or wealth by virtue of their own highlyvalued individual characteristics, such as great athletic or leadership ability, high intelligence, or artistic, political, or scientific talent or achievement. ${ }^{22}$ This supports the analysis of $\mathrm{Bu}$ Tejo character in gaining her achievement through gossip.

The research technique is library research by collecting data. Primary data is the short movie Tilik and secondary is data relates to the research topic in the form of books and articles. The primary data is taken from the conversations and visual data as seen in the Tilik short movie. The data are then identified, described, and analyzed based on the purpose of the research. As in SDT, the conversations and visual data taken which identifies power, prestige, wealth, etc., by individual or a group.

\section{Findings and Discussion}

Tilik is a short film that tells about a group of women from village who want to visit their female leader, Bu Lurah (the mayoress), at a hospital in a city. What interesting about this film is their conversation along the way to the hospital. They went to the hospital in a truck driven by a driver named Gotrek, who was the only male on the trip. In the truck, they gossiped about a woman named Dian. A woman whom they believe as someone who likes to tease someone else's husband, and has unclear job.

The conversation in the truck or gossiping is the main attraction of this short film. What they are gossiping about are trivial matters, something usual in their daily life. Typical gossip itself is indolent and usually used for leisure time only, and because it is relaxing and enjoyable, it does not produce the intended practical results. Gossip is usually relaxed and effortless, and like games, often eases everyday people's

20 Charles Tilly, "Social Dominance: An Intergroup Theory of Social Hierarchy and Oppression by Jim Sidanius, Felicia Pratto," Contemporary Sociology 30, no. No 2 (2001): 120-21.

${ }^{21}$ Felicia Pratto Jim Sidanius, Social Dominance: An Intergroup Theory of Social Hierarchy and Oppression, 2001.

22 Jim Sidanius. 
tensions. ${ }^{23}$ In the short film, how they gossip about a girl named Dian, however, is depicted attractively like a fierce battle between two opposing political camps, Yu Ning who was a relative of Dian, and Bu Tejo, who was the wife of a successful businessman in the village. The battle itself can be said an unbalanced one, for $\mathrm{Bu}$ Tejo turned out to be supported by most ladies in the truck, while Yu Ning fights herself alone.

This short film is very popular, it gains its popularity in just a week. Cawelti highlights two important elements in popular work; first, the standard convention, and second, the needs of escape and relaxation. ${ }^{24}$ The standard convention is a sense of what to expect which means the familiar ground to relate the author (as well the movie maker) and the reader (in this case, the viewers). In Tilik, the common ground is in the forms of Tilik as a social custom and the complex relationship within women association.

As mentioned previously that "tilik" (means visiting) is a common custom in traditional Javanese society as the means to show compassion and sympathy toward others who are in an unfortunate situation. Meanwhile, Adi mentions that as a cultural product, the movie will not be detached from the society that creates and uses it. ${ }^{25}$ Likewise, women association in Javanese culture is popular for its strong bond and sympathy. However, as in everywhere in any group, the relations among human being as the member of the communion are always distinctive and complex. One of the complexity lies in the desire of an individual to be the most powerful and most renowned among others. In Tilik, this role is taken by Bu Tejo. Observing Bu Tejo's behavior is part of the needs of escape and relaxation. The viewers are entertained by $\mathrm{Bu}$ Tejo's exaggerated comical gesture and deed. The need to escape and relaxation arises in the way of viewers' behavior laughing at 'know-it-all' Bu Tejo, but secretly agrees that she reflects many of us.

Understanding the above descriptions, it is important to establish steps in understanding gossip and power depicted by the short movie. First step is the discussion of the usage of gossip and gossiping as method to reach power by describing the facts presented by the movie.

\section{Gossip as a Strategy to Reach Power}

The gossip was opened by Yu Sam by questioning the relationship between Fikri, the son of Bu Lurah, and Dian. This is then used by Bu Tedjo to gain sympathy and support from others in the truck. We can see how Bu Tejo gradually developed her strategy to reach her position as someone who has power. From this point, $\mathrm{Bu}$

\footnotetext{
${ }^{23}$ Aharon Ben-Ze'ev, "The Vindication of Gossip," Good Gossip, 1994.

${ }^{24}$ John G. Cawelti, Adventure, Mystery, and Romance, 1st ed. (Chicago: The University of Chicago Press, 1976).

${ }^{25}$ Ida Rochani Adi, Mitos Di Balik Film Laga Amerika, 1st ed. (Yogyakarta: Gadjahmada University Press, 2008).
} 
Tejo found an opening to begin to show her power. At first, Bu Tejo asked very convincingly what Dian was doing,

Bu Tejo: "Eh Dian iki, gaweane opo yo? Kok jare ono sing tau ngomong yen gaweane iki gak genah ngono kuwi lho. Kan mesaake Bu Lurah tho, yen nganti duwe mantu nggaweane ra nggenah ngono kuwi lho yo. Ono sing tau ngomong yen nggaweane Dian ki mlebu meto hotel ngono kuwi lho. Terus ning mall karo wong lanang barang. Gawean opo yo?!”

"(I wonder what Dian does for living. I heard that she does an inappropriate job. Poor our Bu Lurah, If she's going to have that kind of daughter in-law. Someone said that she often rents a hotel room and goes to the mall with different guys. What kind of job is that?!"

$\mathrm{Bu}$ Tejo's question then led to an opinion that Dian was a bad woman, for she has an uncertain job. She is a woman who should be avoided because it could be that she will bring shame to her family. Bu Tejo's first attack annoyed Yu Ning and tried to convince the audience that $\mathrm{Bu}$ Tejo's allegations were not true.

Yu Ning: "Lha iyo sopo ngerti ngeterke tamu wisata tho yo Bu."

(Maybe she is accompanying tourists, who knows?!)

From the conversation, we can see that $\mathrm{Bu}$ Tejo tries to grasp power by influencing others with her information about Dian. In other words, holding power means the ability to manipulate others to be submissive toward the holder of such power. In the battle of power, there is always another competitor that tries to challenge the holder. In Tilik, such role is played by $\mathrm{Yu}$ Ning. Yu ning is created as the antithesis of Bu Tejo's character. What was said by Bu Tejo then became her weapon to start to gain sympathy from other ladies. Here, Bu Tejo's strategy to gain sympathy becomes apparent. The ladies began to believe what Bu Tejo said. She was so convincing that it made others believe her because she had some information she believed was accurate.

In a debate, someone who has accurate information will win the debate. $\mathrm{Bu}$ Tejo, then, showed a more accurate fact by showing a photo where Dian took a romantic photo with a man. This step further instilled $\mathrm{Bu}$ Tejo's power to the audience. Almost all ladies in the truck, except Yu Ning, then got on her side. With a photo that $\mathrm{Bu}$ Tejo showed, they were sure that what Bu Tejo said was the truth. Beersma and Gerben A. Van Kleef explain that there are basic motives for why people are gossiping. One of them is, gossip is often considered as behavior aimed to manipulate and control other opinions, mostly in a negative direction. ${ }^{26}$ In this short

${ }^{26}$ Beersma and Van Kleef, "Why People Gossip: An Empirical Analysis of Social Motives, Antecedents, and Consequences." 
film, the gossip is aimed to manipulate and control other opinions. Here $\mathrm{Bu}$ Tejo always tries to influence others by the information she has.

Hence, the research concludes that $\mathrm{Bu}$ Tedjo works hard in using gossip to gain the power. The next step to understand the process of gaining the power is to identify the elements which support the delivery of a convincing gossip. The next discussion covers social status, strong appearance, and narration as the quality possessed by $\mathrm{Bu}$ tejo.

\section{Social Status, Strong Appearance and Narration to Relay a Convincing Gossip}

The reason why $\mathrm{Bu}$ Tejo seems to dominate in this conversation has something to do also with her social life. In Javanese culture, people address others by using certain attribution to show relation, respect, and identity. ${ }^{27}$ There are many kinds of attribution, but this research will only discuss "Bu" and "Yu" which highlight the movie. In the movie, Bu Tejo and Bu Tri are emerged as the opposite of Yu Sam and Yu Ning. The following analysis will, in a way, answer to the question in a scene when $\mathrm{Bu}$ Tejo and $\mathrm{Bu}$ Tri refuse to help others pushing the damaged truck. "Bu" is originally derived from "Ibu" which means Mistress (Mrs.). However, in the general use of certain Javanese culture, "Bu" is applied to address a woman with higher social status in society.

In Bu Tejo's case, "Bu" is in front of "Tejo" which is the husband's name suggesting that she is the wife of a man holding a certain status in society. $\mathrm{Yu}$ is derived from "Mbakyu" which is originally used to address older sister. In the general use in society, "Yu" is used to address familiar women that are older than the others. Steve L. Ellyson and John F. Dovidio explain about the relationship between power, dominance, and status. Power is regarded as the ability to influence people to do what he or she wants, while dominance is a tendency to control inter-individual dynamics to create a social hierarchy, and status is a position in a hierarchy given by other members in the social organization. ${ }^{28}$ In this short film, Bu Tejo is characterized as a figure that has a larger share than the others; wearing the most sparkling attire, as well as bright and shiny jewelry in her finger and wrist. Such appearance boosts her confidence as a dominant heroine. She also has the power to control and influence others, and in her social life, she has a high status. Yu Ning and other characters, however, are subordinate individuals and have limited information about Dian. That's why the gossip delivered by $\mathrm{Bu}$ Tejo succeeded since it is also supported by her believable appearance.

${ }^{27}$ F X Nadar, "The Prominent Characteristics of Javanese Culture and Their Reflections in Language Use," Humaniora 19, no. 2 (2007): 168-74.

${ }^{28}$ Steve L. Ellyson and John F. Dovidio, "Power, Dominance, and Nonverbal Behavior: Basic Concepts and Issues .," in Springer Series in Social Psychology, vol. 4, 1985, ebi-ebi, https://doi.org/10.1080/02640828708723925. 
The next outbreak that $\mathrm{Bu}$ Tejo launched to influence and gained the audience's sympathy and raised her position was the information about how Dian had a lot of wealth even though she was just working not for long.

Bu Tedjo: "Yo...cah Wedho nyambut gawe, tur yo duite kok langsung akeh barang kuwi lho, kan yo pertanyaan tho nek ngono kuwi iki?"

"(A girl just got a job, suddenly got that much money. Of course, people were asking around.)"

Working hard is a must in life. If someone takes a shortcut by doing an instant but dirty job and obtaining more than others, it surely creates jealousy. This is how Dian becomes the public enemy, which is on one hand, disrupts the harmony in society but on another side strengthens their solidarity. Thus, regarding social relations like in this short film, there are two functions of gossip. First, is that the bond between the teller and listener can be strengthened to the extent that they spend time in conversation together and perhaps share information for the common good. The second is that the information contained in the gossip may be useful for the listener to know about the target person, assuming that the target person is someone in the listener's social environment so that the listener can pursue the relationship more effectively based on further information obtained about him or her ${ }^{29}$ Here, the ladies know more about a girl named Dian. Besides, this information, according to Bu Tejo, became a rumor also among other people, and this leads to Bu Tejo's suspicion that Dian was not a good woman. However, this attack was immediately repelled by $\mathrm{Yu}$ Ning,

Yu Ning: "Bu Tejo! Njenengan iki ko yo mbok ora waton nek ngendikan."

"(Bu Tejo. Can you please not say something unreasonable?!)"

But $\mathrm{Bu}$ Tejo then attacked her again by pointing out the fact that the villagers were also talking about the same thing.

Bu Tejo: "Lho sa desa ki ngomongke Dian kabeh je. Nang Facebook kuwi yo poda rame ngono kuwi lho. Ndelok wae nang komen-komene."

“(Everybody's talking about her on Facebook already. Just look at those comments.)"

This attack strengthens $\mathrm{Bu}$ Tejo's position as someone who dominates the narration, that Dian was not a good woman, she develops. In a narrative, true or false is not an important thing. In a gossip, one who owns the narrative controls the narrative. On the other side, being alone in such a disadvantage position, Yu Ning

${ }^{29}$ Roy F. Baumeister, Liqing Zhang, and Kathleen D. Vohs, "Gossip as Cultural Learning," Review of General Psychology, 2004, https://doi.org/10.1037/1089-2680.8.2.111. 
becomes fearless. Yu Ning consistently asked $\mathrm{Bu}$ Tedjo to prove clear evidence and give solid proof of the gossip.

"Kalian ini mengalahkan wartawan. Sampe ngurusin seluk beluk kehidupan orang lain."

"(You guys are greater than reporters, aren't you? You are busy taking care of the ins and outs of other people's lives)"

However, one thing that should be noticed from Yu Ning is the motif. Does she have a right and straight motif to defend justice? Or she needs to gain challenge as the owner of power so that if she wins the battle, she may take away such power and influence. Vice versa, the audience is forced to believe the narrative a narrator presents. In this case, Bu Tejo is the narrator who controls the narrative. In the literary tradition, a narrator is very powerful over the narrative he/she constructs. We as readers are forced to believe what the narrator says. Likewise, $\mathrm{Bu}$ Tejo is a narrator who forces the audience to believe her narrative. Eric K. Foster states that to function efficiently in a complex social environment, humans require information about those around them. ${ }^{30} \mathrm{Bu}$ Tejo is a good practical narrator in her complex environment that masters any information well. The character is very vocal in delivering her opinions especially about Dian and the women on the truck tend to listen to her because she has power and wealth that others don't possess.

By taking control of the narrative, Bu Tejo even succeeded in characterizing Dian as a woman whose job was not clear but had a lot of wealth. The narrative was even later strengthened by $\mathrm{Bu}$ Tri:

Bu Tri: "Bu Tejo, Yu Sam, yen menurutku tho, nek Dian iki penggaweane genah, kuwi ora mungkin duwe bondo koyo ngono kuwi. Ho oh ra?"

"(Bu Tejo, Yu Sam, in my opinion, if she had an appropriate job, it would be impossible to own those things, right?)"

In the gossip, Dian is also characterized as a woman who has many boyfriends, likes to tease married men, and is believed to have been pregnant outside of a legal marriage. These bad things then made Dian a public enemy among the ladies on the truck. Lea Elwardt, Labianca, and Wittek argue that the choice of gossip object is driven by considerations for group solidarity and social status. ${ }^{31}$ It is clear that one of Bu Tejo's motives putting Dian as a gossip object is to strengthen her power by gaining comprehensive and complete support from women in the truck which is in the end also unites them as a group.

${ }^{30}$ Eric K. Foster, "Research on Gossip: Taxonomy, Methods, and Future Directions," Review of General Psychology, 2004, https://doi.org/10.1037/1089-2680.8.2.78.

${ }^{31}$ R. Ellwardt, L., Labianca, G. J., \& Wittek, "Who Are the Objects of Positive and Negative Gossip at Work? A Social Network Perspective on Workplace Gossip," Social Networks 34, no. 2 (2012): 193-205. 
Moreover, Dian is described as an orphan and unmarried girl which puts her in a vulnerable social status and easy target of gossip. Niko Besnier mentioned that gossip creates certain clash that breaks the harmony in society. ${ }^{32}$ This is correct to define Bu Tejo and Yu Ning's battle. Their relation is disrupted by their disagreement on certain gossip. However, the act of $\mathrm{Bu}$ Tejo levels up her game by manipulating Dian as the public enemy proves that Niko Besnier theory needs to be improved. As mentioned earlier that Dian as the public enemy has created a feeling of belonging and mutual fear in the group. Hence, gossip can be a strategy to reach power in coordinating people in believing something that is in line with Bu Tejo's will. In the end, it also shows social dominance.

After understanding the instruments support the delivery of gossip, it is important to understand the impact of the gossip. Hence, the next step of discussion focuses on the gossip as dangerous weapon that create disharmony in society.

\section{Dangerous Weapon and Disharmony in Society}

In their open war, the weapon embraced by $\mathrm{Bu}$ Tedjo is stronger and more dangerous, gossip. The sharp weapon not only puts her into the highest position among other people on the truck but also to be the most influential leader. The way $\mathrm{Bu}$ Tejo presents the facts about Dian and the story she conveyed was so captivating to her audience so that everyone began to believe and pay attention to her. Bu Tejo then step by step controls her audience. The narrative she creates made everyone believe in what she said. Regardless of whether Bu Tejo's narrative is correct or not, the people in the truck believed it a lot. Everyone believed her except Yu Ning. She is the only one who does not believe the gossip that was narrated by Bu Tejo, and she is also the only opponent in the heated debate about Dian.

The gossip created by $\mathrm{Bu}$ Tejo was aimed to spread fear in the community. The members of the community are married women who are sometimes insecure about themselves. Gossip about Dian, whether true or false, grows the fear inside them, the fear to compete the younger and prettier girl. This is the reason why most of women on the truck become bystanders. Bystanders are people who know that the crime is performed but refuse neither to help nor participate. The women don't feel any necessity to defend Dian because they are in doubt not only about the gossip on Dian but also their position in the community. Although Yu Sam tends to be neutral and asks the objectivity of Bu Tejo's story, she mostly agrees with Bu Tejo's.

Being participated means being brave, rebellious, and alone like Yu ning. Rather than taking the risk, being bystanders are their safe choice. Therefore, the debate was clearly won by Bu Tejo. She owns the gossip material, and she is also good at narrating it, for what she says is supported by facts she believes are true. The reason $\mathrm{Bu}$ Tejo were so excited to take a lead in the conversation is revealed in a scene in a mosque. Bu Tejo gave some money to Gotrek, the driver. But, he tried to

${ }^{32}$ Besnier, Gossip and the Everyday Production of Politics. 
refuse it, for Yu Ning has already paid him a lot. Bu Tejo forced him to accept it and that it was just a gift that didn't mean anything. From this scene, however, we can see that it is something like a bribe from Bu Tejo's husband, for he is running for the district major.

Up to this scene, it becomes clear why Bu Tejo always wants to be superior in the gossip on the truck. We can see that there is an ulterior motive. When $\mathrm{Bu}$ Tejo mastered the gossip presented there, she prepared herself to become a leader among the ladies. In Indonesian government system, if a husband occupies a government position, then automatically his wife will become the head of PKK (Pembinaan Kesejahteraan Keluarga), a women's organization that deals with family welfare program.

Observing this topic is challenging and thought-provoking since Tilik is a short movie loaded with deep and multilayered contents but presented in a simple and creative method.

\section{E. Conclusion}

Gossip highlights the short movie Tilik. Some people believe gossip and gossiping are merely a method to communicate and relate to other people in society. However, this research showed that gossip is more than that. Gossip is surely a sharp weapon that may attack either the object of gossip or others who is harmed by the formulation of gossip.

Gossip can be activated as a weapon to reach power in a certain group. In Tilik, gossip is employed by Bu Tejo to conquer the group of ladies in the truck to trust her, in short term. While in a long term, she is planning to get people's trust so her husband can run for the next Lurah. Furthermore, gossip can be effective if the person who spreads it has power in the society. Bu Tejo certainly has a higher class and position in the society shown by her glamorous appearance compared to other women in the truck. This appearance puts her as a dominant figure in the truck.

Social dominance is structured by a complex pattern. To simplify it, when an individual or a group is above other(s), it is called dominance. Gossip can be used to dominate others. It will be easier to dominate bystanders. In Tilik, we observed that the majority women are bystanders who follow $\mathrm{Bu}$ Tejo's guidance. They are not offended to follow Bu Tejo's guidance.

This movie reconstructs and rebuilds the traditional romantic formula that always portrays the victory of the weak against the stronger representation. In this traditional formula, the weak usually represents the kindness and goodness, while the stronger character with better and greater resources represents greed and arrogance. Tilik reconstructs such idealism by sending the victory to the stronger representation, $\mathrm{Bu}$ Tejo. Yu Ning is presented as the loser romantic heroin for its failure to defeat $\mathrm{Bu}$ Tejo. 


\section{F. Acknowledgement}

The authors would like to thank the reviewers and editors for their valuable comments and recommendations to improve this article. The authors have no conflict of interest to declare. This research has not been supported by any research fund.

\section{BIBLIOGRAPHY}

Adi, Ida Rochani. Mitos Di Balik Film Laga Amerika. 1st ed. Yogyakarta: Gadjahmada University Press, 2008.

Baumeister, Roy F., Liqing Zhang, and Kathleen D. Vohs. "Gossip as Cultural Learning." Review of General Psychology, 2004. https://doi.org/10.1037/1089-2680.8.2.111.

Beersma, Bianca, and Gerben A. Van Kleef. "Why People Gossip: An Empirical Analysis of Social Motives, Antecedents, and Consequences." Journal of Applied Social Psychology, 2012. https://doi.org/10.1111/j.15591816.2012.00956.x.

Ben-Ze'ev, Aharon. “The Vindication of Gossip.” Good Gossip, 1994.

Besnier, Niko. Gossip and the Everyday Production of Politics. Gossip and the Everyday Production of Politics, 2009. https://doi.org/10.1111/j.17576547.2011.00114.x.

Birchall, CLARE. "Knowledge Goes Pop From Conspiracy Theory to Gossip." Journal of Chemical Information and Modeling 53, no. 9 (2019): 1689-99. https://doi.org/10.1017/CBO9781107415324.004.

Cawelti, John G. Adventure, Mystery, and Romance. 1st ed. Chicago: The University of Chicago Press, 1976.

Christina, Chistina. "The Analysis of Bu Tejo's Language in Short Movie 'Tilik."” Metaphor 3, no. No 1 (2020).

Dunbar, R I M. “The Vindication of Gossip.” Review of General Psychology 8, no. 2 (June 2004): 100-110. https://doi.org/10.1037/1089-2680.8.2.100.

Ellwardt, L., Labianca, G. J., \& Wittek, R. "Who Are the Objects of Positive and Negative Gossip at Work? A Social Network Perspective on Workplace Gossip." Social Networks 34, no. 2 (2012): 193-205. 
Epstein, Joseph. Gossip: The Untrivial Pursuit. 1st ed. Boston: Houghton Mifflin Harcourt, 2011.

Foster, Eric K. "Research on Gossip: Taxonomy, Methods, and Future Directions." Review of General Psychology, 2004. https://doi.org/10.1037/10892680.8.2.78.

Inayaturrobbani, Fakhirah. "Memahami Fungsi Gosip Dalam Masyarakat Melalui Film Pendek 'Tilik."' TONIL: Jurnal Kajian Sastra, Teater Dan Sinema 17, no. 2 (2020): 41-54. https://doi.org/10.24821/tnl.v17i2.4353.

Jim Sidanius, Felicia Pratto. Social Dominance: An Intergroup Theory of Social Hierarchy and Oppression, 2001.

McAndrew, Frank T. "The Science of Gossip: Why We Can't Stop Ourselves." Scientific American Mind, 2008.

Nadar, F X. "The Prominent Characteristics of Javanese Culture and Their Reflections in Language Use." Humaniora 19, no. 2 (2007): 168-74.

Prasetyo, Wahyu Agung. Tilik, 2018.

Ritchie, J., Lewis, J., \& Elam, G. "Designing and Selecting Samples.” In Qualitative Research Practice, 2003.

Solove, Daniel. “'I've Got Nothing to Hide' and Other Misunderstandings of Privacy." San Diego Law Review 44, no. 4 (2007): 745.

Steve L. Ellyson and John F. Dovidio. "Power, Dominance, and Nonverbal Behavior: Basic Concepts and Issues ." In Springer Series in Social Psychology, 4:ebiebi, 1985. https://doi.org/10.1080/02640828708723925.

Suryakusuma, Julie. "Tilik', Sexist Stereotypes and Our Collective Insanity." The Jakarta Post, 2020.

Tilly, Charles. "Social Dominance: An Intergroup Theory of Social Hierarchy and Oppression by Jim Sidanius, Felicia Pratto." Contemporary Sociology 30, no. No 2 (2001): 120-21.

Valentina, Jessicha. "Short Film 'Tilik' Grabs Netizens; Attention with 'Ghibah', 'emak-Emak"."” The Jakarta Post, 2020. 


\section{Guidelines}

\section{Submission of Article}

urnal Adabiyah welcomes the articles submission with the main themes on Humanities and Islamic Studies with the emphasis on interdisciplinary and intertextuality approach. Adabiyah is thematicly published twice in a year. ie the theme of the humanities in June and the Islamic Study in December.

Themes related to Islamic Studies are textual studies, scriptural traditions, Islamic law, and theology; and those related to Humanities are language, literature, history, and culture. This scholarly journal Guarantees that the editor decision based on the peer review results will not exceed 30 days from the paper submission date.

Authors are invited to read our archives; to find the relevant topics for the journal, and to submit complete unpublished scientific researches, which are not under review in any other conferences or academic journal.

\section{PUBLICATION ETHIC}

Publication Ethic and Malpractice Statement

Jurnal Adabiyah is a peer-reviewed journal, published twice a year by the Faculty of Adab and Humaniora, Alauddin State Islamic University of Makassar Indonesia. It is available online as open access sources as well as in print. This statement clarifies ethical behaviour of all parties involved in the act of publishing an article in this journal, including the author, the editor-in-chief, the Editorial Board, the reviewers, and the publisher. This statement is based on COPE's Best Practice Guidelines for Journal Editors.

Ethical Guideline for Journal Publication

The publication of an article in Jurnal Adabiyah, is an essential building block in the development of a coherent and respected network of knowledge. It is a direct reflection of the quality of the work of the authors and the institutions that support them. Peer-reviewed articles support and embody the scientific methods. It is therefore important to agree upon standards of expected ethical behavior for all parties involved in the act of publishing: the author, the editor, the reviewer, the publisher, and the society. As the publisher of Jurnal Adabiyah, the Faculty of Adab and Humaniora takes its duties of guardianship over all stages of publishing seriously and it recognizes its ethical and other responsibilities. The Faculty of Adab and Humaniora committed to ensuring that advertising, reprint or other commercial revenue has no impact or influence on editorial decisions.

\section{Publication Decisions}

The editors of Jurnal Adabiyah is responsible for deciding which articles submitted to the journal should be published. The validation of the work in question and its importance to researchers and readers must always drive such decisions. The editors may be guided by the policies of the journal's editorial board and constrained by such legal requirements as shall then be in force regarding libel, copyright infringement, and plagiarism. The editors may confer with other editors or reviewers in making their decisions.

\section{Plagiarism Screening}

It is basically author's duty to only submit a manuscript that is free from plagiarism and academically malpractices. The editor, however, will check all submitted papers through Turnitin.

\section{Fair Play}

An editor at any time evaluates manuscripts for their intellectual content without regard to race, gender, sexual orientation, religious belief, ethnic origin, citizenship, or political philosophy of the authors. 


\section{Confidentiality}

The editors and any editorial staff must not disclose any information about a submitted manuscript to anyone other than the corresponding author, reviewers, potential reviewers, other editorial advisers, and the publisher, as appropriate.

\section{Disclosure and Conflicts of Interest}

Unpublished materials disclosed in a submitted manuscript must not be used in editors' own research without the express written consent of the author.

\section{DUTIES OF AUTHORS}

\section{Reporting Standards}

Authors of reports of original research should present an accurate account of the work performed as well as an objective discussion of its significance. Underlying data should be represented accurately in the paper. A paper should contain sufficient detail and references to permit others to replicate the work. Fraudulent or knowingly inaccurate statements constitute unethical behaviour and are unacceptable.

\section{Originality and Plagiarism}

The authors should ensure that they have written entirely original works, and if the authors have used the work and/or words of others that this has been appropriately cited or quoted.

\section{Multiple, Redundant, or Concurrent Publication}

An author should not in general publish manuscripts describing essentially the same research in more than one journal or primary publication. Submitting the same manuscript to more than one journal concurrently constitutes unethical publishing behaviour and is unacceptable.

\section{Acknowledgement of Sources}

Proper acknowledgment of the work of others must always be given. Authors should cite publications that have been influential in determining the nature of the reported work.

\section{Authorship of the Paper}

Authorship should be limited to those who have made a significant contribution to the conception, design, execution, or interpretation of the reported research. All those who have made significant contributions should be listed as co-authors. Where there are others who have participated in certain substantive aspects of the research project, they should be acknowledged or listed as contributors. The corresponding author should ensure that all appropriate co-authors and no inappropriate co-authors are included on the paper, and that all co-authors have seen and approved the final version of the paper and have agreed to its submission for publication.

\section{Disclosure and Conflicts of Interest}

All authors should disclose in their manuscript any financial or other substantive conflict of interest that might be construed to influence the results or interpretation of their manuscript. All sources of financial support for the project should be disclosed.

\section{Fundamental errors in Published Works}

When an author discovers a significant error or inaccuracy in his/her own published work, it is the author's obligation to promptly notify the journal editor or publisher and cooperate with the editor to retract or correct the paper.

\section{PLAGIARISM}

It is basically author's duty to only submit a manuscript that is free from plagiarism and academically malpractices. The editor, however, will check all submitted papers through Turnitin. 


\section{AUTHOR GUIDELINES}

\section{Guidelines for online submission:}

1. Author should first register as Author to the website of Jurnal Adabiyah. Click the menu "register" to register as an author.

2. Once after the author is registered, please login to the website of Jurnal Adabiyah and submit the article through online submission (with the stat us of active submissions).

3. The article should follow the standard template of Jurnal Adabiyah provided in the website.

4. The citation and bibliography should follow the Turabian citation style.

5. Author is restricted not to send his/her article to another journal before having confirmation from the editorial team (approximately 4 weeks right after the article submitted).

6. Author should follow editorial decisions and recommendations related to the article completion. All reviews and assessements will be informed through online submission.

Article submitted to Jurnal Adabiyah editorial board must follow these guidelines:

1. Article should be based on the scientific research in the field humanities and Islamic studies;

2. Article must be an original work and has not been previously published;

3. Article should be written in Arabic or English languages;

4. Article must be typed in one-half spaced on A4-paper size;

5. Article's length is about $6,000-10,000$ words;

6. All submission must include a 150-250 word abstract;

7. Abstract should be written in 3 languages; Arabic, English, and Bahasa;

8. Full name(s) of the author(s) must be stated, along with his/her/their institution and complete address;

9. All submission should be in OpenOffice, Microsoft Word, RTF, or WordPerfect document file format;

10. Bibliographical reference must be noted in footnote and bibliography according to Jurnal Adabiyah style. In addition, it is suggested for author(s) to use reference manager tools such

\section{as MENDELEY or 7 otero}

When a source is cited for the first time, full information is provided: full name(s) of author(s), title of the source in italic, place of publication, publishing company, date of publication, and the precise page that is cited. For the following citations of the same source, list the author's last name, two or three words of the title, and the specific page number(s). The word ibid., op.cit., and loc.cit. are may not be used any more.

\section{Example in footnotes:}

${ }^{1}$ Mircea Eliade (ed.), The Encyclopedia of Religion, vol. 8 (New York: Simon and Schuster, 1995), h. 18.

${ }^{2}$ Norman Daniel, Islam and the West (Oxford: One World Publications, 1991), h. 190.

${ }^{3}$ Syeikh Ja'far Subhāni, Mafăhim Al-Qur'ān (Beirut: Mu'assasah Al-Tarīkh Al-'Arabī, 2010)., Juz 5, h. 231. 
${ }^{4}$ Syeikh Ja'far Subhānī, Mafāhim Al-Qur'ān, h. 8-9.

\section{Example in bibliography:}

Subhānī, Syeikh Ja'far. Mafăhim Al-Qur'ān. Beirut: Mu'assasah Al-Tarīkh Al-’Arabī, 2010.

Eliade, Mircea (ed.). The Encyclopedia of Religion, vol. 8. New York: Simon and Schuster, 1995.

Daniel, Norman. Islam and the West. Oxford: One World Publications, 1991.

Shihab, Muhammad Quraish. Sunnah-Syiah Bergandengan Tangan: Mungkinkah? Kajian Atas Konsep Ajaran Dan Pemikiran. Cet. III. Jakarta: Lentera Hati, 2007.

\section{Detail informations of the footnotes:}

1. Holy book

Al-Qur'ân, Al-Baqarah/2: 185.

Perjanjian Baru, Mrk. 2: 18.

2. Qur'anic translation

${ }^{1}$ Departemen Agama RI, al-Qur'an dan Terjemahannya (Jakarta: Darus Sunnah, 2005), h. 55.

3. Book

${ }^{1}$ Muḥammad 'Ajjaj al-Khațib, Ușl al-Hadith: 'Ulumuh wa Mușțalaḥ uh (Beirut: Dâr al-Fikr, 1989), h. 57.

4. Translation Books

${ }^{1}$ Toshihiko Izutsu, Relasi Tuhan dan Manusia: Pendekatan Semantik terhadap al-Qur'an, terj. Agus Fahri Husein dkk (Yogyakarta: Tiara Wacana, 2003), h. 14.

5. Voluminous book

${ }^{1}$ Muḥammad al-Ṭâhir b. 'Ashur, al-Tahrīir wa al-Tanwīr, Vol. 25 (Tunisia: Dâr al-Suhûn, 2009), h. 76.

${ }^{1}$ Muḥammad b. Ismā‘īl al-Bukharī, al-Jami‘ al-Ṣaḥịh, Vol. 2 (Beirut: Dar al-Kutub al-‘Ilmı́yah, 1999), h. 77.

6. Article in book

${ }^{1}$ Sahiron Syamsuddin, "Metode Intratekstualitas Muhammad Shahrur dalam Penafsiran al-Qur'an" dalam Abdul Mustaqim dan Sahiron Syamsuddin (eds.), Studi al-Qur'an Kontemporer: Wacana Baru Berbagai Metodologi Tafsir (Yogyakarta: Tiara Wacana, 2002), h. 139.

7. Article in encyclopaedia

${ }^{1}$ M. Th. Houtsma, "Kufr" dalam A. J. Wensinck, at al. (ed.), First Encyclopaedia of Islam, Vol. 6 (Leiden: E.J. Brill, 1987), h. 244.

8. Article in journal

${ }^{1}$ Muhammad Adlin Sila, "The Festivity of Maulid Nabi in Cikoang, South Sulawesi: Between Remembering and Exaggerating the Spirit of Prophet", Studia Islamika 8, no. 3 (2001): h. 9.

9. Article in mass media

${ }^{1}$ Masdar F. Mas'udi, "Hubungan Agama dan Negara”, Kompas, 7 Agustus 2002. 
10. Article in Internet

${ }^{1}$ Muhammad Shahrūr, "Reading the Religious Teks: a New Approach" dalam http://www.shahrour.org/25 Februari 2010/diakses 5 Juni 2010.

11. Thesis or dissertation

${ }^{1}$ Syahruddin Usman, "KinerjaGuru Penddikan Agama Islam pada SMAN dan SMKN Kota Makassar”, Disertasi (Makassar: PPs UIN Alauddin, 2010), h. 200.

\section{COPYRIGHT NOTICE}

Authors who publish with this journal agree to the following terms:

1) Authors retain copyright and grant the journal right of first publication with the work simultaneously licensed under a Creative Commons Attribution License that allows others to share the work with an acknowledgement of the work's authorship and initial publication in this journal.

2) Authors are able to enter into separate, additional contractual arrangements for the non-exclusive distribution of the journal's published version of the work (e.g., post it to an institutional repository or publish it in a book), with an acknowledgement of its initial publication in this journal.

3)Authors are permitted and encouraged to post their work online (e.g., in institutional repositories or on their website) prior to and during the submission process, as it can lead to productive exchanges, as well as earlier and greater citation of published work (See The Effect of Open Access). 